\title{
PAIN AND THE CHALLENGE OF INTERDISCIPLINARITY IN CHILD CARE
}

\author{
Maria José Menossi ${ }^{1}$ \\ Regina Aparecida Garcia de Lima \\ Adriana Katia Corrêa ${ }^{3}$
}

Menossi MJ, Lima RAG, Corrêa AK. Pain in children and adolescents with cancer. Rev Latino-am Enfermagem 2008 maio-junho; 16(3):489-94.

In the light of the multiple dimensions involving the phenomenon of pain in children and adolescents with cancer, this study aimed to present a reflection on interdisciplinary practice as a healthcare resource for these patients. The study focused on the aspects related to the need for this practice in the aforementioned context and the challenges of its implementation. These reflections support the acknowledgement that the articulation among several aspects of knowledge in a common project is essential to contemplate the multiple dimensions that compose healthcare forchildren and adolescents with cancer in pain situations. However, these articulations should not only be theoretical, but also built by the professionals involved in this practice.

DESCRIPTORS: pain; neoplasms; child; adolescent; patient care team

\section{DOLOR Y RETO DE LA INTERDISCIPLINARIDAD FRENTE AL CUIDADO DEL NIÑO}

Teniendo en consideración múltiples dimensiones que involucran el fenómeno dolor en el niño y adolescente con cáncer, este trabajo tuvo por objetivo presentar una reflexión sobre la práctica interdisciplinaria como un recurso para el cuidado de estos clientes. Serán enfocados aspectos relacionados con la necesidad de esa práctica dentro de un contexto explicito y los retos para su implementación. Esas reflexiones brindan subsidios que permiten reconocer que la articulación de los diversos conocimientos en torno a un proyecto común es esencial para ue sean consideradas sus múltiples dimensiones, las que componen el cuidado al niño y al adolescente con cáncer en situaciones de dolor. Es necesario que esas articulaciones no sean apenas teóricas, sino también construidas por los profesionales involucrados.

DESCRIPTORES: dolor; neoplasias; niño; adolescente; grupo de atención al paciente

\section{A DOR E O DESAFIO DA INTERDISCIPLINARIDADE NO CUIDADO À CRIANÇA}

Tendo em vista as múltiplas dimensões que envolvem o fenômeno da dor da criança e do adolescente com câncer, este trabalho objetivou apresentar reflexão sobre a prática interdisciplinar como recurso para o cuidado dessa clientela. Foram enfocados aspectos relativos à necessidade dessa prática no contexto explicitado e os desafios para sua implementação. Essas reflexões trazem subsídios que permitem reconhecer que a articulação dos diversos saberes, em torno de um projeto comum, é essencial para que sejam contempladas as múltiplas dimensões que compõem o cuidado à criança e ao adolescente com câncer, em situações de dor. Todavia, é necessário que essas articulações não sejam somente teóricas, mas construídas pelos profissionais envolvidos.

DESCRITORES: dor; neoplasias; criança; adolescente; equipe de assistência ao paciente

${ }^{1}$ RN, University of São Paulo at Ribeirão Preto Medical School Hospital das Clínicas, Brazil; Doctoral student, e-mail: mjmenossi@uol.com.br; ${ }^{2}$ Associate Professor, e-mail: limare@eerp.usp.br; ${ }^{3}$ Ph.D., Faculty, e-mail: adricor@eerp.usp.br. University of São Paulo at Ribeirão Preto College of Nursing, WHO Collaborating Centre for Nursing Research Development, Brazil 


\section{PAIN IN CHILDREN AND ADOLESCENTS WITH CANCER}

Cancer is a health problem with broad geographical variations. Data presented by the World Health Organization (WHO), referring to epidemiological studies, indicate that, out of one million children from 0 to 14 years old, around 130 develop cancer every year, and it is estimated that 7,000 new cases appear every year. In developed countries, cancer is the main cause of death by disease in children from 01 to 14 years old. Around $67 \%$ of these children can be cured if the disease is diagnosed early and treated properly, even though the cure depends on the specific type of cancer. In developing countries, however, the disease is generally found at an advanced stage by the time it is diagnosed, and curative treatment often is not possible, so the treatment is directed towards palliative care ${ }^{(1)}$.

In Brazil, most cancer records are organized by age, categories with periods of five years, and by the primary location of the tumor, which is an inadequate format for the pediatrics area, since tumors in children are classified by cyto or histopathologic type, not by primary tumor topography, except for tumors in the Central Nervous System. Moreover, there are significant variations in specific rates by age, year by year, and many infant demographic standards cannot be expressed using such long periods of time ${ }^{(2)}$.

Studies developed in specific centers for pain treatment in developed countries indicate that all children with cancer experience pain, which is related to their disease or to the treatment, and over $70 \%$ of them sometimes present severe pain. Even though there is a concern with pain relief, it is often not recognized, or, when it is, it may be treated inappropriately, even with enough available resources ${ }^{(1)}$.

Pain has been defined by the International Association for the Study of Pain (IASP) as "an unpleasant sensorial and emotional experience, associated to real or potential tissue injuries or described in terms of such injuries" (1)

People use the term pain in relation to their traumatic experiences. It is always subjective, a sensation in one or more parts of the body. It is always unpleasant, and consequently, an emotional experience $^{(1,3)}$.
Each person experiences this painful feeling in a different way, considering several factors: the person's life history, sociocultural context, type of personality and situation at the time. Expressing pain or denying it will be a consequence of these particularities ${ }^{(4-5)}$. In a painful situation, however, along with the presence of functional-organic components and social and cultural issues, there are also intimate components related to the way people experience this specific situation, in their singularity.

Considering all these factors involved in the painful experience, it can be noticed that taking care of pain is not an easy task, and when it comes to oncologic pain in children and adolescents, these aspects become even more present ${ }^{(3)}$.

This broad view of pain was advocated by Dr. Cicely Saunders, by attributing a meaning to cancer pain, asserting that is not only physical, but also emotional, social and spiritual, associated to financial, interpersonal and mental dimensions of pain, the pain of the family and the healthcare team. She also supports that the human language is limited and deficient to describe the countless possibilities and paradoxes inherent to the impact pain generates on the behavior of the patient, family members and health professionals as the disease evolves. However, the term "total pain" can be used didactically in order to sensitize people about the variety of sources that may be related to cancer pain ${ }^{(6)}$.

Besides the objective aspects that must be evaluated, the comprehension of other contextual data, involving the patient with cancer, is also necessary for the application of an evaluation to define guidelines for efficient therapeutic approaches.

The pain of children and adolescents with cancer can be caused by the tumor itself (which may affect soft tissue, bones, viscera, central or peripheral nervous system, including compression on the spinal cord), by the tumor treatment (postoperative pain, dermatitis induced by radiotherapy, gastritis by repetitive vomiting, persistent headache after spinal puncture, bone alterations induced by corticoids, neuropathy from medication origins, infections, mucositis), by the procedures (venous punctures, spinal puncture, bone marrow biopsy) and incidental factors like traumatisms and common pains during

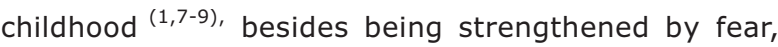
anxiety and uncertainty. 
In the light of the multiple dimensions involving the pain of children and adolescents with cancer, the challenge of building an interdisciplinary practice is presented as something essential. This construction is relevant in the current health context, since the construction of integral healthcare is one of the fundamental principles of the Single Health System, both regarding the integrated organization of services, in their different healthcare levels, and in terms of the perspective to understand man as an individual whose biological, psychological, social and cultural dimensions are articulated, which makes it impossible to separate them according to tight, severe limits.

In this context, interdisciplinary practice is presented as a resource that may allow the construction of integrality in healthcare - specifically, in this study, the construction of integral healthcare to children and adolescents with cancer in a painful situation.

Therefore, this study aimed to present a reflection on interdisciplinary practice as a resource for healthcare provided to these children and adolescents. This reflection is part of another study (10), which had the purpose of describing and analyzing the experiences of healthcare professionals who provide care to children and adolescents with cancer, in pain situations, during the hospitalization process, in the perspective of complexity.

\section{THECONSTRUCTIONOF INTERDISCIPLINARY HEALTHCARE TO CHILDREN AND ADOLESCENTS IN PAIN SITUATIONS, FROM THE PERSPECTIVE OF COMPLEX THINKING}

Aimed at reflecting theoretically on the construction of integral healthcare to children and adolescents with cancer in pain situations, this study was based on Edgar Morin's ideas about Complex Thinking (11-12).

Edgard Morin was born in France in 1921. He is internationally well-known in the academic and scientific areas as one of the most important thinkers nowadays, and has dedicated his work, among other subjects, to the study and systematization of an epistemology of complexity. This author develops the idea of the need for a complex way of thinking for the construction of multidimensional knowledge, in line with the complexity of reality. He proposes a renovation of ways of thinking, in terms of integrating mankind and the cosmos, in a totalizing rather than reducing point of view, considering the qualities of the parts and the whole simultaneously, as well as their relations ${ }^{(13)}$.

Therefore, this study considers the problem of pain in children and adolescents with cancer as a complex phenomenon, whose comprehension needs to include the multiple dimensions that compose it, and this is the challenge proposed by the Complexity Paradigm: "handling the multidimensional characteristics of the entire reality under study" (12)

In the construction of interdisciplinary healthcare to children and adolescents with cancer in a situation of pain, the articulation of actions and differentiated knowledge of professionals acting in the healthcare process should be taken into account, as well as the dynamics of the group processes that also comprise subjective questions.

The work process in healthcare, even though its organization is based on several professionals practice, is marked by the determination of actions, which generally maintain the logic of fragmentation of the treated child and adolescent. The integral human dimension is lost in the disruption of the socalled biological, psychological and social dimensions. Each of these dimensions ends up being considered as the focus of a single professional who works in isolated actions, at non-concomitant moments.

This also reflects the comprehension of the health-disease process in the biologistic logic and, even though this comprehension is magnified into an integral perspective, for instance, by new professional education processes, this will not always be translated into daily actions marked by a broader view. The difficulty ist to transform the accumulated knowledge into collective actions.

The authors of this study agree that the establishment of effective interdisciplinary communication is not only a matter of theoretical articulations, but also articulation among the individuals involved in this practice ${ }^{(14)}$. From what has been exposed so far, it is worth considering the need for the articulation of knowledge and the construction of a common project among the professionals.

In the perspective of complexity, Edgar Morin proposes a method of circular articulation among the several fields of knowledge, highlighting the need for 
the contextualization of both physical and biological knowledge in a culture, society, history and mankind. Thus, the possibility of a communication circuit among the sciences is created, from which the transdisciplinary science will be able to emerge through "reflexive circulation", since the anthroposocial refers to the biological, which refers to the physical, and which finally refers back to the anthroposocial ${ }^{(12,15)}$.

Therefore, this study indicated the need to renew the ways of thinking that allows for the reconnection of knowledge, stressing the importance of a way of thinking that understands that the knowledge of the whole depends on the knowledge of the parts, and also that the knowledge of the parts depends on the knowledge of the whole - it is important to recognize and examine the multidimensional phenomena, without isolating each of these dimensions in a mutilating way - and that may respect the differences at the same time as it recognizes the unity: "It is necessary to replace an isolating and separating way of thinking with one that distinguishes and unites. It is necessary to replace a dissociative and reducing way of thinking with a complex way of thinking, in the original meaning of the term complexus: something that is braided together"(16).

Some authors ${ }^{(14,16-17)}$ have emphasized the importance of overcoming the excessive strengthening of the disciplines, searching for alternative disciplinary ways that may allow for multiple perspectives on current problems.

More than a conceptual issue of the terms inter-multi-poli-transdisciplinarity, the notion of cooperation is essential, i.e. the notion of the construction of a common project ${ }^{(16)}$. In other words, thinking of what is "braided together" once more evidences the need for articulation of all professionals involved in the healthcare provided to children and adolescents with cancer in situations of pain, so that this healthcare unit is made viable through a jointlybuilt common project.

In this notion of a common project, the specializations are not disregarded, but the possibility of its integration is created around a common field. In this case, the care directed to the pain of children and adolescents with cancer involves the articulation of several professional categories (physician, nurse, assistant and nurse technician, psychologist, nutritionist, social worker, physical therapist), and also among professionals with different specializations in the same professional category (pediatrician, oncologist, surgeon, neurologist and anesthesiologist).

Returning to the interdisciplinary issue, in the perspective of constructing a common project, the notion of the shared view should be mentioned. In this conception, even though individuals have particular points of view on a broader reality, they share the responsibility for the whole, not only for their part. The emergence of shared points of view is a long process that demands frequent conversations, which should be open and available to arrange a variety of ideas, helping new possibilities of joint action to emerge ${ }^{(18)}$. This idea incorporates the hologramatic principle proposed by Edgar Morin ${ }^{(11-12)}$.

For the sake of an example, the author also uses a metaphor of the hologram, which says that, even apart, each part shows the intact image of the whole. Thus, if a photograph is cut into pieces, each part will show only a piece of the image, but if a hologram is divided in several parts, each of them will show the image of the whole, from a different point of view though. Each "piece" of the hologram provides a different angle of the same image ${ }^{(18)}$.

The notion of strategy emerges for the materialization of a working proposal interlined in an interdisciplinary axis. This notion is contrary to that of a program. In a program, there is a pre-determined sequence of actions, whose functioning depends on the circumstances that permit its compliance, whereas the strategy considers the unexpected, the new, in the context of changing or improving its action. Therefore, if the circumstances are adverse, the program fails, whereas a strategy, on the contrary, uses new circumstances to build new scenarios ${ }^{(11)}$.

It is also worth highlighting that the act of building interdisciplinary care, according to the perspective indicated here and considering the articulation of the subjects, also means dealing with the complexity of the human relationships developed in teamwork. While teamwork may have a creative potential meaning, it can also cause the emergence of processes that hinder the healthy exchange of ways of thinking, being and acting.

The obstructive processes in the social systems, groups and institutions are related, among other aspects, to the idea that men do not only gather 
to defend themselves against natural dangers or to guarantee their survival, but also to instrumentalize their power and control over other men ${ }^{(19)}$.

Therefore, when common objectives are not considered, the magnified meaning of being together with the other for the benefit of, in this case, integral healthcare to children and adolescents with cancer in situations of pain, in the construction of a collective project is unfeasible.

A common project also demands commitment from the institution, in order to provide conditions for interdisciplinary work, by creating spaces that promote a dialog among professionals. According to the latter, it is necessary to invest in the building of teams that are able to understand the complexity involved in care delivery to children and adolescents with cancer in pain situations, not only from the theoretical point of view, but also in the healthcare process itself. In other words, it is necessary to assure the integrality of actions during all stages of this process, through the articulation of the professionals involved in each moment: in the evaluation of the best treatment, considering the different components present in these patients' pain; in the evaluation of the efficacy of the actions implemented and in the indication of changes and the introduction to new actions. In order to achieve this, it is essential that every member of the team values collective work, which does not mean denying one's own difficulties by considering the permanent interference of interpersonal and social issues, since people always present themselves based on their own ideas, values, formation and social spaces.

These difficulties involve conflicts that can be worked out, by allowing for collective creation, or denied, hindering changes in healthcare organization, or even by generating an unbearable work environment. This shows that these professionals have to build and watch over teamwork on a permanent basis. Moreover, it is necessary to consider that dealing with children and adolescents with cancer in painful situations may cause feelings of hopelessness and impotence to the professionals, in the light of the daily contact with the limits of human existence. Thus, the creation of a support structure for the care of the group itself is essential.

\section{FINAL CONSIDERATIONS}

As $\mathrm{WHO}^{(1)}$ indicates, the current priority in the care of children and adolescents with cancer in pain situations is related to the application of the knowledge produced in clinical practice. In order to meet this purpose, the authors believe that, once again, there are evidences of the need for an interdisciplinary practice.

Considering the complexity present in the activity areas of health professionals who provide care to children and adolescents with cancer in pain situations, the act of rethinking healthcare in a global and integrating point of view, allowing the application of the knowledge produced in clinical practice, involves the development of a strategy that, interlined in the articulation of the several areas of knowledge of the professionals involved in this care, may be built in the light of the context it is developed in, and rebuilt for every new scenario or unpredicted event.

At first sight, the interdisciplinary construction for integral healthcare delivery to children and adolescents with cancer in painful situations may seem a utopia. Nevertheless, "... utopias are generally either associated to impossible things to accomplish, or to vain wishes. On the other hand (...) they are essential to feed the imagination towards the elaboration of projects. All human beings should have utopias, in terms of being able to imagine a world that would work in a more appropriate way. Not the personal world of each person, but the human society in a broader sense" (20).

\section{REFERENCES}

1. World Health Organization (WHO). Cancer pain relief and palliative care in children. Geneva, England: WHO; 1998. 2. Ministério da Saúde (BR). Instituto Nacional do Câncer. Ações de enfermagem para o controle do câncer: uma proposta de integração ensino-serviço. $2^{a}$ ed. Rio de Janeiro: INCA; 2002.
3. Haagedoorn EML, Oldhoff J, Bender W, Clarke WD, Slejfer

D. Cancer pain management. In: Essential oncology for healthy professionals. The Netherlands: Van Gorgum, Assen; 1994. p. 325-40.

4. Schechter NL, Berde CB, Yaster M. Pain in infants, children, and adolescents: an overview. In: Pain in infants, children, and adolescents. Baltimore: Williams \& Wilkins; 1993. p. 3-9. 
5. Figueiró JA. A dor. São Paulo (SP): Publifolha; 2000.

6. Schisler EL. O conceito de dor total no câncer. In: Schulze CMN. Dimensões da dor no câncer: reflexões sobre o cuidado interdisciplinar e um novo paradigma de saúde. São Paulo (SP): Robe; 1997. p. 49-62.

7. Cordeiro SM, Coeli M. Dor aguda na criança. In: Drummond JP. Dor aguda: fisiopatologia, clínica e terapêutica. São Paulo (SP): Atheneu; 2000. p. 151-70.

8. McGrath PJ, Beyer J, Cleeland C, Eland J, McGrath PA, Portenoy R. Report of the subcommittee on assessment and methodologic issues in the management of pain in childhood cancer. Pediatr 1990; 86(5): 814-7.

9. Miser AW. Management of pain associated with childhood cancer. In: Schechter NL, Berde CB, Yaster M. Pain in infants, children, and adolescents. Baltimore: Williams \& Wilkins; 1993. p. 411-23.

10. Menossi MJ. A complexidade da dor da criança e do adolescente com câncer hospitalizados e as múltiplas dimensões do seu cuidar. [dissertação]. Ribeirão Preto(SP): Escola de Enfermagem de Ribeirão Preto/USP; 2004.

11. Morin E. Introdução ao pensamento complexo. $3^{a}$ ed. Lisboa: Stória Editores; 2001.

12. Morin E. Ciência com consciência. $6^{\mathrm{a}}$ ed. Rio de Janeiro (RJ): Bertrand Brasil; 2002.

13. Petraglia IC. Edgar Morin: a educação e a complexidade do ser e do saber. 7a ed. Petrópolis (RJ): Vozes; 2002.

14. Almeida Filho N. Transdisciplinaridade e saúde coletiva. Ciênc. Saúde Coletiva 1997; 2(1-2): 5-20.

15. Vasconcellos EM. Complexidade e pesquisa interdisciplinar: epistemologia e metodologia operativa. Petrópolis (RJ): Vozes; 2002.

16. Morin E. A cabeça bem-feita: repensar a reforma, reformar o pensamento. $5^{a}$ ed. Rio de Janeiro (RJ): Bertrand Brasil; 2001.

17. Platino CA. A crise dos paradigmas e a crise do conceito de paradigma. In: Brandão Z. A crise dos paradigmas e a educação. São Paulo (SP): Cortez; 1994. p. 30-47.

18. Senge PM. A quinta disciplina: arte e prática da organização de aprendizagem. São Paulo (SP): Best Seller; 1998.

19. Osorio LC. Processos obstrutivos nos sistemas sociais, nos grupos e nas instituições. In: Zimerman D, Osório LC. (org). Como trabalhamos em grupos. Porto Alegre (RS): Artes Médicas; 1997. p. 69-74.

20. Machado JM. Educação: Projetos e valores. São Paulo (SP): Escrituras Editora; 2000. 